\title{
Európa modern egységesülése és tagozódása
}

\section{Cohesion and diversification in modern Europe}

\author{
NEMES NAGY JÓZSEF, SZABÓ PÁL
}

NEMES NAGY József: egyetemi tanár, Eötvös Loránd Tudományegyetem, Regionális Tudományi Tanszék; 1117 Budapest, Pázmány Péter sétány 1/c.; nemesnagy@t-online.hu SZABÓ Pál: egyetemi docens, Eötvös Loránd Tudományegyetem, Regionális Tudományi Tanszék; 1117 Budapest, Pázmány Péter sétány 1/c.; szabopalpeter@t-online.hu

KULCSSZAVAK: Horváth Gyula; Európa; térszerkezet; területi egyenlőtlenségek; regionális politika

ABSZTRAKT: Horváth Gyula kutatói életpályáján a kezdetektől központi szerepet játszott az európai térfolyamatok és regionális politika kutatása. A szerzők e tanulmánnyal tisztelegnek emléke előtt.

A tanulmány különböző térbeli léptékekben mutatja be az európai térszerkezeti tagozódás stabil és változó elemeit, a területi fejlettségi különbségek alakulásának tendenciáit. Ezen belül részletesen foglalkozik a makroregionális tagozódás meghatározó földrajzi dimenzióival, az égtájak szerinti sokelemű különbségeket és a centrum-periféria megosztottságot létrehozó tényezőkkel és folyamatokkal. Az írás felidézi a területi egyenlőtlenségek térszerkezeti sajátosságait generalizáltan bemutató, sok esetben az eltérő konfigurációkat kiemelo", a tudományos és publicisztikai forrásokban egyaránt gyakran felbukkanó grafikus modelleket.

A tanulmány áttekinti az országokon belüli térségi szintek és térfelosztások kérdéskörét, a regionális egységek szerepében meglévő különbségeket, a térfelosztások változásait. Az Európai Unió regionális politikai cél- és eszközrendszerének, a regionális politika főbb szakaszainak bemutatása mellett - a 2004-2014 időszakra vonatkozóan - a közösségen belüli pénzügyi transzfereket külön is elemzi. A szerzők szerint ez utóbbi témakör társadalmi és politikai megítélése, az egyes országok esetében meglehetősen egyoldalú. Az országokon belüli területi fejlettségi különbségeket tekintve Európában mindmáig kimutatható az országos gazdasági fejlettségi szint és a belső differenciáltság közötti negatív korreláció.

A tanulmány egyrészt állást foglal az európai és hazai regionális politikában újabban tapasztalható egyoldalú városközpontú fordulattal szemben, elsősorban azért, mert e megközelítés veszélyezteti a területi konvergenciacélok elérését. Másrészt rámutat a kontinens globális beágyazottságának jelentőségére, az országos szintű szabályozás még ma is meghatározó súlyára a területi irányításban. Kiemelt jelentőségü problémakörként jelöli meg a határok változó szerepét a kontinens modern történetében és napjaink aktuális történéseiben.

József NEMES NAGY: professor, Department of Regional Science, Eötvös Loránd University; Pázmány Péter sétány 1/c., H-1117 Budapest, Hungary; nemesnagy@t-online.hu

Pál SZABÓ: associate professor, Department of Regional Science, Eötvös Loránd University; Pázmány Péter sétány 1/c., H-1117 Budapest, Hungary; szabopalpeter@t-online.hu

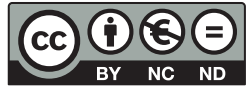


KEYWORDS: Gyula Horváth; Europe; spatial structure; regional inequalities; regional policy

ABSTRACT: Even from the beginning of Gyula Horváth's research career, European regional processes and policies played a central role for him. With this study, the authors salute his memory.

This paper studies the continent's most important geographic, economic, social and political dimensions, and its changing territorial structure after World War II. It describes the social-spatial structure's permanent and variable elements and the changes in regional development inequalities on different territorial levels. Furthermore, it analyzes in detail the geographic dimensions determining macro-regional divisions and the factors producing differentiations along the cardinal directions and center-periphery relations. The paper cites generalized graphical spatial structure models of the continent which are often used in scientific and political papers to illustrate and highlight spatial differences.

The paper looks through the in-country territorial levels and spatial subdivisions, the differences between the roles of the regional units, and the changes of spatial differentiation. Besides presenting the main periods, objectives and tools of EU regional policy, it also analyzes the financial transfers within the Community during the 2004-2014 period. We think that in some countries the social and political evaluation of this theme is too much one-sided. Furthermore, in many cases, other important parts of social management (e.g. the idea and the institutions of territorial decentralization) or the evaluation of the market's determining role and territorial effects took a back seat. As these mechanisms' combined effects, there is a negative correlation between the countries' development level and their degree of inter-regional development inequality. In the more developed central countries the regional inequalities are lower than in the peripheral ones, and in most of the latter countries, the dominant trend is an increase of territorial (and social) differentiations.

This paper disputes the newly modified European and Hungarian regional policies' onesided focus on cities because it threatens its another often cited objective of territorial cohesion. The study highlights the importance of the continent's global and the national legislation's still dominant role in territorial governance. According to the paper, the changing role of the borders is a significant problem area in the continent's modern history and actual situation.

\section{Bevezetés}

Horváth Gyula tudományos munkásságában a hazai folyamatok vizsgálatának kereteként, sok tekintetben mintaadó háttereként, kiemelt szerepű az európai területi fejlődés és a regionális politika kutatása. Számos, nagy visszhangot kiváltó munkája is ebben a témakörben született. A kutatói életpálya kezdetén - amikor elsősorban a szocialista országok területi folyamatait kutatta, a maitól alapjaiban eltérő politikai és tudományos viszonyok között - önmagában a területi, területfejlesztési szempont megjelenítése is újdonságnak számított. A keleti blokkban ez a szemlélet ugyanis nem volt privilegizált helyzetben, sőt a maga „veszélyes”, decentralizáló, demokratizáló tartalma miatt még a gazdaságpolitika is óvatosan kezelte, nem beszélve a finomabb struktúrákat érintő társadalmi dimenziókról. A tudományos kutatás műhelyeiben azonban már ekkor nyilvánvalóvá vált, hogy a kontinens szerencsésebb felén folyamatosan erősödő súllyal, tényszerủ alátámasztottsággal, strukturált intézményrendszerrel, célzott finanszírozási eszközökkel jelenik meg új részpolitikaként a regionális politika, a területfejlesztés. Ez a hatás aztán feltartóztathatatlanul tört 
előre (és nemcsak az olajválság, de a regionális politikai gondolat sem állt meg a határokon, amelyek akkor még alig voltak átjárhatók), és a regionális politika a rendszerváltozás után belépett az elfogadott társadalomirányítási dimenziók közé. Horváth Gyulának, a formálódó hazai regionalista közösség tagjaként, majd hamarosan vezető szereplőjeként kiemelkedő szerepe volt ebben a folyamatban, amely alkalmazható mintaként, a társadalmi modernizáció fontos eszközeként mutatta be a nyugat-európai regionalista gondolatot (benne a centralizált irányítás ellensúlyaként elgondolt és formálódó új entitásokat, a régiókat). Tőle olvashattunk először átfogó elemzést az „észak-dél probléma” európai mintaországáról, Olaszországról (Horváth 1993), majd a sajátos államszervezetű Nagy-Britanniáról (Horváth 1997), és összegző munkájában az európai regionális politikáról (Horváth 1998). Az ezt követő években már a hazai adaptáció tudományos teendői kerültek munkásságának középpontjába. A tragikusan és váratlanul megtört életpálya utolsó szakaszában sajátos módon tér vissza a kezdetekhez, de már teljesen új helyzetképről tudósítva. Angol nyelven megjelent monográfiája (Horváth 2015) azt mutatja be, hova jutott a kelet-középeurópai (benne a hazai) regionális tudomány intézményesülése, miként lett e makrorégióban (az EU-n belül és azon kívül is) a regionális fejlesztési gondolat elfogadottá, tudományos és gyakorlati munkák alapjává.

Horváth Gyula tudományos munkásságának hatásai már ma is túlnyúlnak a saját publikációkon, és megjelennek egy széles, a regionális tudomány, a területfejlesztés és a „régióügy” iránt elkötelezett, aktív, tehetséges tanítványi kör munkáiban. Tanulmányunkban a kontinens térszerveződésének és területfejlesztési, irányítási tapasztalatainak néhány, általunk is kutatott témakörének felidézésével, a hagyományosabb geográfiai közelítések és a regionalista problémakörök átgondolásával tisztelgünk szeretett kollégánk, barátunk emléke előtt.

\section{Európa makroregionális tagozódása és térszerkezete}

Európa minden természeti meghatározottságával, vitatható határaival együtt sem pusztán a természetföldrajzi nómenklatúrákba sorolható kategória, hanem azonosítható társadalmi és politikai téregység, egységesülésének és tagozódásának tartalma és mozgatórugói is elsődlegesen társadalmiak és politikaiak.

Valamely nagyobb téregységen belül az egységesülés és tagozódás jellemzői és folyamatai mind térbeli, mind időbeli szempontból erősen léptékfüggők. A különböző térségi szinteken, eltérő belső térfelosztás mellett eltérő jegyek lehetnek meghatározók, a két irányzat egyidejűleg más tendenciákat mutathat, különbözhetnek a rövid, közép- és hosszú távú jellemzők. Mindez azzal jár, hogy - kiragadva egyik vagy másik térbeli vagy történeti méretet - a következtetések is eltérhetnek. Az is igaz, hogy a különböző léptékekben megfigyelhető sajátosságok nem függetlenek egymástól, hanem át is szövik egymást. A lokális 
folyamatok a globális léptékűekkel is kapcsolatban vannak és viszont, a markáns rövid távú hatások (válságok) nagy távlatban is éreztethetik hatásukat. Ezeket a nagyon általános összefüggéseket a területi kutatások során is érdemes szem előtt tartani, mert beszorulva egy szűkebb térméretbe (például a régiók szintjére) lényeges mozgatórugók hatása esik ki a magyarázatokból.

Terry G. Jordan amerikai geográfus szerint Európa egyszerre egységes és sokszínű (Jordan 1996). Ha különböző hangsúlyokkal, tartalmakkal is, de ugyanez az általános megállapítás van jelen a kontinens térfolyamatait elemző hazai szakirodalomban is (Cséfalvay 1999; Horváth 1998, 2006; Probáld 2000; Probáld, Szabó 2005; Rechnitzer 1999).

Amikor a különböző társadalmi, gazdasági jelenségeket (nyelv, vallás, urbanizáció szintje, mezőgazdasági termelés, infrastrukturális ellátottság, gazdasági fejlettség stb.) vizsgáljuk, többféle területi mintázat tárható fel, ugyanakkor Európa társadalmi, gazdasági megosztottságában évtizedek óta jellegzetes, bár sokat vitatott tagoló dimenziók az észak-dél, kelet-nyugat, valamint a centrum-periféria relációk.

A makrorégiók közötti társadalmi, gazdasági különbségekre tekintve Braudel (2003) szerint az európai kontinensen két európai világ, Észak és Dél osztozott és osztozik, történelmük legalább annyira megkülönbözteti őket, mint az éghajlatuk, ellentéteik pedig elemi erővel vonzzák egymást. Az észak-dél reláció a szocialista rendszerek bukása előtti időkben volt igazán a nyugati regionalisták nézőpontjának fókuszában (Kunzmann 1992) és vált a geodesign kedvelt térviszonylatává, ám a kontinens „újraegyesítésével” ez a megközelítés veszített súlyából, a politikai, gazdasági változásokkal felértékelődött a keletnyugati kapcsolatok jelentősége (Rechnitzer 1998).

Az észak-dél reláció látványos háttere az éghajlati zonalitás, erre épülve bemutatható az ellentét egyrészt a mezőgazdasági termelés eltérő lehetőségeiben, a növénytermesztés és az állattenyésztés eltérő arányaiban, a népesség területi elhelyezkedésében (északi területek ritka népsűrüsége), sőt a táplálkozási, italfogyasztási szokásokban is (Gottmann 1954; Grigg 1998; Jordan 1996; Sárfalvi 1968). E különbségeken alapulva aktív kereskedelem jöhetett létre: Pounds (1997) szerint régen a kereskedelem inkább működött észak és dél, mint nyugat és kelet között. Ennek következményeként rajzolódott ki az európai közlekedés nagyszerkezetében az észak-dél irányú kapcsolatok fölénye, mely az 1980-1990-es évekig tartott (Erdősi 2004). Más okokból, de az észak-dél reláció több kultúrföldrajzi tényezőnél is felbukkan: például Jordan (1996) az egykori Római Birodalom határaival hozza összefüggésbe a jelenlegi kulturális, vallási és nyelvi különbségeket - megfigyelhető a protestáns Észak és a katolikus Dél ugyan nem vonalszerü, de érzékletes kettéválása, valamint északon a germán, délen a latin nyelvcsoport dominanciája. Emellett a történelmi időkben dél felől érkező iszlám hódítás társadalmi, kulturális nyomait, az iszlám vallás szórványos elterjedtségét Dél-Európában találjuk, bár ezeket az arányokat az utóbbi időben módosította a jelentős számú arab bevándorló közép- és 
nyugat-európai letelepedése. Az észak-dél viszonylat a politika színterén is megjelent, Soós (1996) szerint - még az Európai Unió kibővítése előtti időszakban - a Régiók Bizottságán belül is jelentkezett ez a reláció, az erős és gyenge régiók közötti érdekmegosztottsággal, az alkotmányos és törvényhozói hatáskörök különbözőségével, a politikai és adminisztratív kultúra eltérő jellegével magyarázhatóan.

A fejlett Észak és az elmaradottabb Dél párosa nemcsak a fejlettségi térképeken, hanem sok elemzésben is kiemelten megjelölt makroregionális összetevője a kontinensnek (Landesmann 2013; Terrasi 2003). E szembenállásban érdekes történelmi inverzó is megjelenik: Pounds (1997) szerint Dél és Észak, Attika és Skandinávia között az európai történelem egyetlen szakaszában sem volt olyan óriási a kulturális szintkülönbség a Dél javára, mint az i. e. 5. század közepén (délen késő vaskor és északon késő őskőkor). A középkorra azonban fordult a helyzet: a korábban virágzó Dél-Európa elvesztette vezető szerepét. Egyedül Észak-Olaszország tudott lépést tartani valamelyest az Észak fejlődésével, míg az egykor virágzó spanyol és portugál területek kiterjedt gyarmatbirodalmaik ellenére sem tudtak érdemi gazdasági fejlődést produkálni. A fejlett Észak, elmaradott Dél reláció fokozatosan erősödött. Ebben Max Weber szerint fontos elem, hogy a római katolikus - és még nagyobb mértékben a görögkeleti - egyház kevésbé tudott megbirkózni a valláserkölcs és az egyre nagyobb teret hódító általános polgári (protestáns) erkölcs kettősségével. Az ipari forradalom, a fordista gazdaság alapjai is inkább északon voltak meg, az ellentét így tovább fokozódott az elmúlt évszázadokban. Az észak-dél szembenállás a 20. század vége felé viszont oldódni látszott, mivel posztfordi gazdaság révén, amerikai mintára, egy fejlődő déli - sunbelt (napfény) - övezet alakult ki a nyugati mediterráneumban, modern iparral, kutatás-fejlesztési központokkal, dinamikus turizmussal, vonzó élettérrel. Mindez azonban nem tudott billenteni az alapreláción, sőt, a 2000-es évek végi gazdasági válság a déli területek jelentős részének „mélyrepülését” okozta. (Ekkor jelent meg a nagyobb dél-európai országok és Írország neveinek kezdőbetűiből a PIIGS mint negatív töltetű betűszó.)

Az észak-déli relációnál, többek szerint, már régóta markánsabb a nyugatkelet ellentét a kontinensen: Európa jelenlegi területi társadalmi-gazdasági differenciáltsága esetében több szempontból a legfontosabb választóvonal - a korábbi évtizedek politikai-gazdasági jellemzői miatt - az Európai Unió korábbi (EU 15-ök) keleti határán húzódik (Probáld 2000). Az ipari forradalom ugyancsak polarizálta a kontinenst a nyugat-kelet pozíció mentén: Sárfalvi (1968) szerint a második világháború előtt - több-kevesebb általánosítással - két, nagyjából homogén részt lehetett elkülöníteni, az ipari Nyugat-Európát és a parasztok Kelet- (és Dél-) Európáját. Ehhez a 2. világháború utáni korszakban éles politikai megosztottság is párosult: meghatározóvá vált a tőkés „Nyugat” és a kommunista „Kelet” szembenállása. A vasfüggöny oly egyértelműen osztotta ketté Európát (parlamentáris demokrácia, piacgazdaság, NATO, EGK stb., illetve pártállami diktatúra, tervgazdaság, Varsói Szerződés, KGST stb.), hogy ehhez 
képest minden más makroregionális különbség elhalványult, és ahogy a gazdasági különbségnek az észak-dél, úgy a politikai szembenállásnak a nyugat-kelet reláció vált a metaforájává Európában. A rendszerváltozások után több szempontból megindult a közeledés a két kontinensrész között, ám a múlt hagyatéka még mindig erős, és az Európai Unió 2004. évi bővítésével az integráció legkomolyabb területi problémájává vált ez a reláció (ami aztán a belső forrásallokációs vitákban, a támogatásokért folyó versengésben is kulcskérdéssé vált).

A nyugat-kelet ellentét is nyomozható természeti tényezőkben, legmarkánsabban az Atlanti-óceánhoz való viszonyban, a „tengeri” és a „szárazföldi” Európa megnevezésével (Gottmann 1954; Pap 1997). Lassan halványuló északdéli futású, az egykori szocialista tömb nyugati peremén húzódó demográfiai választóvonal is kimutatható a kontinensen (Probáld 2000), amelytől nyugatra például a várható élettartam, az idős népesség aránya magasabb, a csecsemőhalandóság alacsonyabb (bár a demográfiai feszültségek ma szinte egyetemleges problémának tekinthetők a kontinensen). A mezőgazdaság tekintetében - bár az éghajlat is meghatározó nyugat-kelet viszonylatban, óceáni és kontinentális kontrasztban - fö jellemző, hogy az intenzív művelés Nyugatot jellemzi, míg az extenzív Keletet, és a foglalkoztatás tekintetében a mezőgazdaság szerepe még mindig nagyobb a keleti részen. A fő ipari, gazdasági centrumok, a nagyvállalatok központjai Nyugaton vannak, Kelet inkább csak gazdasági holdudvarként (leányvállalatok, olcsó munkaerő stb.) funkcionál. A szolgáltató szektor értékés foglalkoztatotti túlsúlya is Nyugaton markáns. Heidenreich (2003) településföldrajzi különbözőséget is számba vesz: míg Nyugaton számos világváros és policentrikus városegyüttes van, addig Keleten egyközpontú agglomerációk fejlődtek ki, leszámítva egy lengyel várostömörülést. Erdősi (2004) pedig arra hívja fel a figyelmet, hogy a politikai változások nyomán a közlekedési igények által kikényszerítetten előtérbe kerültek a nyugat-kelet irányú közlekedési fejlesztések.

Mindezen tényezőket mintegy összegező megkülönböztető jegy a fejlettségbeli differencia, a jövedelemben, az életszínvonalban megjelenő különbség. Heidenreich (2003) szerint Kelet-Európa a 15. századig csak csekély hátrányban volt Nyugat-Európához képest, majd az olló nyílni kezdett. Ez utóbbit Sárfalvi (1994) is megállapítja, rámutat viszont arra is, hogy később, a 18. századtól a 20. század elejéig fokozatos közeledés mutatkozott Európa nyugati és keleti fele között. A két világháború között a fejlődés ismét a dezintegráció irányába tartott, a 2. világháború utáni elkülönülés pedig konzerválta a fejlettségi különbségeket (Sárfalvi 1994), miközben a két rész külön-külön az integrálódás útjára lépett (még ha e két folyamat alaptartalma, mechanizmusa, intézményrendszere teljesen el is tért), ami Kelet-Közép-Európa számára megrekedt fejlődést, a dél-európai országok számára viszont felzárkózást hozott. Sárfalvi véleménye szerint - a keleti tömb felbomlása után megindult sokelemű összekapcsolódás ellenére - a szakadék mélyebb volt Nyugat és Kelet között az 1990-es évek közepén, mint a 20. század elején vagy akár a két világháború között. Manapság sincs olyan fejlettséghez köthető, elterjedt mérőszám, amely a Nyugat és Kelet 
közötti ellentétet ki ne mutatná, annak ellenére, hogy a nyugati és keleti országok közötti fejlettségbeli „lépcső” mára lejtővé simult, azáltal, hogy a „keleti éltanulók" (Szlovénia, Csehország) - legalábbis a közismert gazdasági fejlettségi mutatókban - beérték a „nyugati lemaradókat” (Portugália, Görögország).

A harmadik kiemelt térreláció a centrum-periféria viszony. E fogalompár legalább három, egymással összekapcsolódó, de egymástól el is váló jelentést hordoz: helyzeti (földrajzi), fejlettségi (gazdasági), hatalmi (társadalmi) viszonyt (Nemes Nagy 2009). Európa esetében lényeges, hogy a kontinens gazdasági és társadalmi centruma - ha az európaiságát tekintve megkérdőjelezhetetlenül a kontinenshez tartozó Oroszországot leválasztjuk - jelenleg a földrajzi értelemben vett centrumtérségben lelhető fel, amelyet körülölel az elmaradottabb periféria.

A különböző társadalomföldrajzi jegyek közül a centrum-periféria relációt igazolják a magterületet jellemző nagy népességi és gazdasági súly, a magas népsűrűség, a magas urbanizáltság, valamint az átlagnál magasabb egy főre jutó jövedelem és (időben, a konjunkturális hatások következtében változékonyabban) az alacsonyabb munkanélküliség. Az európai centrumban találhatók a nagy ipari koncentrációk, magas a szolgáltatások értéktermelési és foglalkoztatási aránya, sűrű a távközlési és közlekedési hálózat, itt lelhetők fel a legnagyobb cégek központjainak helyi koncentrációi, nagy a kulturális és oktatási potenciál, bőséges a globálisan vonzó idegenforgalmi attrakció stb., de a túlzsúfoltság, a környezetszennyezés magas foka is itt figyelhető meg (Hospers 2002; Lever 1995; Probáld 2000). Jordan (1996) szerint - bizonytalanabb értéktartalmai miatt ugyan inkább csak vitára felhívó megállapításként - e viszonyrendszer még a kultúrföldrajzban is tetten érhetö. A centrumból a periféria felé haladva csökken az „európaiság” - kulturális értelemben. A centrum-periféria kettősségen túl az e reláció szerinti többszörös tagozódást, koncentrikus körökben modellezhető zonalitást is többen felfedezni vélik. Ilyen például a szolgáltatói alapú magterület, az ipari karakterü - a magterületet körülölelő - átmeneti területek és a periferiális helyzetű mezőgazdasági területek (Hospers 2002) hármasa (aminek történeti előzménye Delaisi modellje 1929-ből: ipari magterület és agrárjellegű periféria), vagy például az általános gazdasági fejlettség (GDP/fövel mérve) alapján kimutatható belső és külső magterület, illetve belső és külső peremvidék (Nagle, Spencer 1999).

Összességében ma Európát egy összetett makroregionális fejlettségi kép jellemzi, amelyben kisebbrészt az észak-dél, nagyobbrészt a centrum-periféria és nyugat-kelet relációk szerepelnek. A kontinens - csak égtájak szerinti - tagolása ennél összetettebben is értelmezhető: például összegző ábráján Probáld (2000) hét területi egységet (Észak-, Nyugat-, Dél-, Kelet-, Nyugat-Közép-, KeletKözép- és Délkelet-Európa) különít el, és nyolc makrorégiót mutat Jordan (1996) kultúrföldrajzi Európa-modellje is, amelyben a három kiemelt - eddig ismertetett - reláció metszetei révén állnak elő az eltérő makrorégiók.

Mindezen térségi relációk látványos vizuális formái jelentek meg a térszerkezeti modellekben (pontosabban térszerkezeti ábrákban). A hazai szerzők 
körében is hamar ismertté vált a földrajzi és gazdasági centrumtérséget szimbolizáló Brunet „Kék banánja” (Horváth 1998; Probáld 2000), majd a szakirodalomban is megjelentek és a területpolitika központi mühelyeit is ellepték a további kívánatos zöldségek, gyümölcsök és egyéb grafikus szimbólumok. Ilyen például a fejlődési kisugárzást mutató „Kék csillag” (Horváth 1998), a zónák és csomópontok kombinációját felmutató „Vörös polip” (Kozma 2003), vagy a szükebb tereket modellezo” „Európai napfényövezet” (Sunbelt) és a „Közép-európai bumeráng" (Rechnitzer 1998). E modellek számszerü adatokkal történő tesztelése a hazai kutatói körökben is megindult (Kincses, Nagy, Tóth 2013; Probáld, Szabó 2005; Szabó 2009). A számítások valójában csak a gyengülő „Banán-modell" relevanciáját tudták kimutatni, valamint azt, hogy egyre inkább erősödik ezzel szemben Kunzmann-nak az 1990-es években bevezetett, a nagyvárosok térszerkezeti vázszerepét tükröző úgynevezett „Szőlő-modellje”, amely szerint a nagyvárosok - a centrumban és a perifériákon egyaránt - egyre jelentősebb társadalmi, gazdasági koncentrációt alakítanak ki, amivel elszakadnak vidékies környezetüktől (Szabó 2015). E - sok elemükben erősen vitatható - modellek és fejlődéstörténetük vitathatatlanul lényeges térszerkezeti átalakulást is tükröz: a jelenlegi társadalmi és gazdasági folyamatok a városi és a vidéki Európára való megosztottsághoz vezethetnek, amely a jövőben akár a kontinens legmarkánsabb területi relációjává válhat (ESPON 2004, 2014).

Felmerül a kérdés, hogy e röviden jellemzett tagozódási dimenziók miként jelentek/jelennek meg az Európai Unió szakpolitikai gondolkodásában és akcióiban. Az Európai Unió hivatalos dokumentumaiban is találkozhatunk különböző térfelosztásokkal. Például a Europe 2000+-ban (EC 1994) az alábbi térségeket különítették el: Központi helyzetủ nagyvárosok térsége, Alpi ív, Atlanti ív, Északitengeri régiók, Kontinentális átló, Új területek [volt NDK], Mediterrán régiók, Ultraperifériák, Északi országok, Közép- és Kelet-Európa, Dél- és Kelet-Mediterráneum. Egy későbbi uniós dokumentumban (EC 2001) pedig a központi régiók, közbenső régiók, periferiális régiók kategóriákat találjuk. Az elmúlt időszakból az EU szakminiszterei által aláírt új Területi Agenda és annak háttéranyaga (2012) tartalmaz makrorégiókat. A magyarországi elnökség idejére esett e dokumentum megújítása, ekkor négy - a fent említett 2000+ felosztásához képest nem túl szofisztikáltan megnevezett - makrorégiót különítettek el a kontinensen: Nyugat, Észak, Dél és Kelet (Sütő, Salamin, Szabó 2010).

Az Európai Unióban nyilvánvaló a különböző „térségi lobbik” müködése is, amelyek nem pusztán országhatárokkal lehatárolt térségeket érintenek. Már maga a Lisszaboni szerződés is megfogalmazta, hogy az elmaradott régiókon túl a hegyvidéki, tengerparti területek, szigetek, ritkán lakott (északi) térségek is kiemelt figyelmet érdemelnek. (Bár a mi felfogásunkban ugyanilyen figyelmet érdemelnének sajátos problémáik miatt a síkvidéki vagy éppen a tengertől elzárt térségek is.) Az első hivatalos formációk a Balti-tengeri régió, majd a Duna régió voltak, később még létrejött a Jón-Adriai és külön az Alpi régió. (Utóbbi az Alpok-Adria korábbi formáció egyfajta kettéválásaként is értelmezhető.) E tér- 
ségekre elkészültek a makroregionális stratégiák is. Ezek ugyan szakmailag érdekes kezdeményezésnek tűntek, ám megkapták az EU regionális politikájától a „három nemet”: a stratégiák megvalósításához nem hoznak létre sem új intézményeket, sem új jogszabályokat és új uniós források sincsenek céljaikra, legfeljebb a meglévő forrásokat irányíthatják e térségekbe. Hangsúlyozták viszont,

1. táblázat: Pénzügyi transzferek egyenlege az Európai Unió költségvetésében, 2004-2014 Operating budgetary balance in the EU (2004-2014)

\begin{tabular}{|c|c|c|c|c|c|c|c|c|c|c|c|c|}
\hline \multirow[t]{3}{*}{ Ország } & \multicolumn{12}{|c|}{ Támogatási / befizetési többlet } \\
\hline & \multicolumn{11}{|c|}{$a$ GNI \%-ában } & \multirow{2}{*}{$\begin{array}{c}\text { mió } € \\
2014\end{array}$} \\
\hline & 2004 & 005 & 006 & 007 & 2008 & 2009 & 2010 & 2011 & 2012 & 2013 & 2014 & \\
\hline \multicolumn{13}{|c|}{ Nettó támogatott országok } \\
\hline Magyarország & 0,24 & 0,69 & 1,29 & 1,70 & 1,11 & 3,05 & 2,95 & 4,62 & 3,47 & 5,08 & 5,64 & 5681 \\
\hline Bulgária & $\ldots$ & $\ldots$ & $\ldots$ & 1,13 & 1,92 & 1,77 & 2,50 & 1,88 & 3,32 & 3,80 & 4,45 & 1824 \\
\hline Litvánia & 2,06 & 2,30 & 2,48 & 2,84 & 2,67 & 5,44 & 4,94 & 4,55 & 4,69 & 4,45 & 4,38 & 1543 \\
\hline Lengyelország & 0,72 & 0,77 & 1,12 & 1,70 & 1,25 & 2,09 & 2,43 & 3,03 & 3,24 & 3,22 & 3,47 & 13748 \\
\hline Lettország & 1,72 & 1,94 & 1,52 & & 1,69 & 2,49 & 3,70 & 3,62 & 4,33 & 3,46 & 3,35 & 799 \\
\hline Románia & $\ldots$ & $\ldots$ & 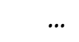 & 0,49 & 1,14 & 1,42 & 0,99 & 1,10 & 1,55 & 2,94 & 3,09 & 4519 \\
\hline Görögország & 2,16 & 1,98 & 2,39 & 2,40 & 2,68 & 1,35 & 1,62 & 2,29 & 2,33 & 2,93 & 2,89 & 5162 \\
\hline Észtország & 1,57 & 1,43 & 1,38 & 1,50 & 1,46 & 4,18 & 4,82 & 2,25 & 4,64 & 4,22 & 2,49 & 473 \\
\hline Málta & 0,93 & 1,82 & 1,95 & 0,50 & 0,50 & 0,15 & 0,84 & 1,00 & 1,03 & 1,21 & 2,35 & 179 \\
\hline Szlovénia & 0,40 & 0,35 & 0,46 & 0,26 & 0,31 & 0,68 & 1,18 & 1,34 & 1,60 & 1,20 & 2,17 & 794 \\
\hline & 0,30 & 0,17 & 0,33 & 0,51 & 0,78 & 1,23 & 1,44 & 0,96 & 2,02 & 2,33 & 2,08 & 3004 \\
\hline Portugália & 2,08 & 1,52 & 1,42 & 1,46 & 1,57 & 1,27 & 1,51 & 1,73 & 3,06 & 2.63 & 1,88 & 3211 \\
\hline Szlovákia & 0,51 & 0,71 & 0,73 & 1,13 & 1,13 & 0,85 & 2,06 & 1,69 & 2,26 & 1,78 & 1,37 & 1010 \\
\hline & 0,49 & 0,64 & 0,67 & $-0,06$ & $-0,10$ & $-0,01$ & 0,06 & 0,03 & $-0,13$ & 0,23 & 0,69 & 114 \\
\hline Horvátország & 0,07 & 0,12 & 0,26 & 0,18 & 0,29 & 0,24 & 0,20 & 0,26 & 0,24 & 0,12 & 0,42 & 173 \\
\hline Spanyolo. & 1,00 & 0,66 & 0,38 & 0,35 & 0,26 & 0,11 & 0,38 & 0,28 & 0,38 & 0,29 & 0,10 & 1090 \\
\hline & & 0,77 & 0,67 & 0,39 & 0,35 & $-0,03$ & 0,58 & 0,27 & 0,47 & 0,19 & 0,02 & 38 \\
\hline \multicolumn{13}{|c|}{ Nettó befizetö országok } \\
\hline & 0,38 & 0,49 & & 0,47 & 0,43 & $-0,02$ & 0,29 & 0,34 & 0,36 & 0,42 & 0,71 & 4711 \\
\hline Svédország & 0,34 & 0,27 & 0,25 & 0,27 & 0,40 & 0,03 & 0,32 & 0,32 & 0,44 & 0,49 & 0,52 & 2312 \\
\hline Németország & 0,31 & 0,26 & 0,26 & 0,29 & 0,34 & 0,25 & 0,35 & 0,33 & 0,42 & 0,48 & 0,52 & 15501 \\
\hline Finnország & 0,04 & 0,05 & 0,14 & 0,09 & 0,16 & 0,30 & 0,16 & 0,33 & 0,33 & 0,30 & 0,40 & 809 \\
\hline & 0,15 & 0,11 & 0,11 & 0,20 & 0,12 & 0,14 & 0,23 & 0,26 & 0,34 & 0,39 & 0,38 & 1240 \\
\hline Belgium & 0,18 & 0,19 & 0,21 & 0,25 & 0,20 & 0,48 & 0,39 & 0,36 & 0,38 & 0,39 & 0,37 & 1478 \\
\hline Franciaország & 0,18 & 0,16 & 0,16 & 0,15 & 0,19 & 0,30 & 0,27 & 0,30 & 0,39 & 0,39 & 0,33 & 7164 \\
\hline Dánia & 0,11 & 0,12 & 0,22 & 0,26 & 0,22 & 0,42 & 0,25 & 0,33 & 0,44 & 0,49 & 0,32 & 836 \\
\hline Olaszország & 0,20 & 0,15 & 0,11 & 0,12 & 0,25 & 0,32 & 0,28 & 0,36 & 0,31 & 0,24 & 0,28 & 4467 \\
\hline N.-Britannia & 0,15 & 0,08 & 0,10 & 0,19 & 0,04 & 0,11 & 0,31 & 0,30 & 0,36 & 0,43 & 0,23 & 4929 \\
\hline Luxemburg* & 0,42 & 0,33 & 0,25 & 0,48 & 0,07 & 0,42 & 0,16 & 0,27 & 0,28 & 0,24 & $-0,27$ & -80 \\
\hline
\end{tabular}

* Írország 2009-ben, Ciprus 2007-2009-ben és 2012-ben befizetési többletü volt. Hollandia 2009-ben, Luxemburg 2014-ben támogatási többletü volt.

Adatok forrása: http://ec.europa.eu/budget/figures/interactive/index_en.cfm 
hogy bíznak a közösen megfogalmazott célokban és a koordinált megközelítésben, így a szinergikus hatásokban és a meglévő uniós alapok és más pénzügyi eszközök hatékonyabb felhasználásában. Azaz a makrorégiók integrált területi keretet jelenthetnek a közös jellemzőkből származó közös kihívások kezelésére, erősítve a társadalmi, gazdasági kohézión túl a területi kohéziót is.

Az alapvető tagoló dimenziók - a mára 28 tagúvá bővült Európai Unióban - a „legszárazabb” s egyben talán a legérzékenyebb számadatokban, a költségvetési befizetések és támogatások egyenlegében is látványosan jelen vannak (1. táblázat). A centrumországok és a perifériák, Kelet és Nyugat, Észak és Dél egyértelmüen elkülönülnek.

A tág kelet-közép-európai periféria - amelynek országai már a csatlakozás előtt is részesültek uniós támogatásokban, előcsatlakozási eszközökben - egyöntetűen támogatási többletű (a relatív mértéket tekintve 2014-ben éppen Magyarország vezette ez sort). E körbe tartoznak még a korábbi időszak perifériáinak képviselői is (Spanyolország, Portugália), egyedül a regionális tagoltságáról is közismert Olaszország vált „centrumpozíciójúvá”. A legnagyobb nettó befizeto Németország és a legnagyobb összeggel támogatott Lengyelország egyenlege azonos nagyságrendű. Ezek az adatok a befizetési többletű centrumországok tekintetében relatíve (a GNI százalékában kifejezve) még vállalható szolidaritási terhet jeleznek. A végső befizetési-támogatási egyenlegekben - a nem túl nagy szélsőségek kialakulása mögött - a nagy súlyú agrártámogatások állnak, (amelyekből minden tagország szabályozottan normatív módon részesül), illetve a kutatás-fejlesztési programokban elsődleges haszonélvezőnek számító fejlett nyugati országok kedvező pozíciója is kitűnik. A pénzügyi redisztribúciós mechanizmus egyben az EU müködésének „szimbolikus” eleme is, ha hatása nem is hasonlítható a spontán piaci tőkeáramlások erejéhez. Ez a pénzügyi mechanizmus az újonnan csatlakozott vagy épp csatlakozni szándékozó országok számára egyértelműen kiemelt vonzerő, a tagország esetében sajátos térfelosztási „trükkök” hordozója is (a legújabb példát a magyar "lyukasrégió”-kezdeményezés adja, a föváros és Pest megye kettéválasztásával). De mindez már átvezet egy más térségi szint, a régiók problematikájához.

\section{Régiók a regionális politikában}

A kontinens makroregionális tagozódása mellett a belső tagolás és tagozódás is hasonlóan sokszínű. A tagolás egyrészt a politikai és közigazgatási beosztás (települések, régiók, országok) mentén halad. Másrészt Európát többfelé darabolják az országokat más-más csoportosítású nemzetközi vagy európai politikai, gazdasági, katonai szervezetek, társadalmi, politikai együttműködések (pl. EU, EFTA, FÁK, OECD, NATO, visegrádi országok). Ezek közül a kontinens egységessége felé való törekvést képviselő Európai Unió emelkedik ki, amelyet nemcsak 
országok, hanem nevesített szereplőként számos régió is alkot. Az EU erre a mezoszintre kiemelt figyelmet fordít: a régiókat az 1980-as évek végén a közösségi regionális politika felfutása, majd az 1990-es évek elején a Maastrichti szerződés állította reflektorfénybe, és ezzel együtt megjelent a „régiók Európája” gondolat, a mezoszintek szerepe az Európai Unióban felértékelődött (Horváth 2000). Az egyes országok régiói, regionális szintjei ugyanakkor - közigazgatási és egyéb funkcióik, kompetenciáik szempontjából - rendkívül sokszínűek.

A regionális politikában a támogatási elvek változása (a regionális alapú támogatások megjelenése) miatt szükség volt egy egységes rendszerre, ennek érdekében dolgozták ki a hierarchikus térségi szintrendszert és téregységi nómenklatúrát, az úgynevezett NUTS rendszert (Nomenclature des unités territoriales statistiques). A NUTS a tagállamok javaslatai és jóváhagyása alapján született meg az EU statisztikai hivatalában (Decand 1997), és már az 1970-es évek elejétől használatban volt statisztikai adatgyüjtéshez (Eurostat REGIO-adatbázis). 1988-tól - amikor a regionális politika (Strukturális Alapok - EC 1988) kijelölte a régiók szerepét az elosztási rendszerben - használják rendszeresen a közösségi politikában (EC 1999). A rendelet akkor két regionális szintet jelölt ki a regionális támogatás célterületének, amelyek a fejlesztési politika alanyai lettek (Horváth 2003), később már csak egy szint, a NUTS 2 maradt meg a regionális politika használatában, de ennek szerepe még a 2014-2020-as ciklusban is kiemelt jelentőségü. Magára a NUTS-jegyzékre vonatkozó előírás, s így a rendszer és szabályozása 2003-ben kifinomult jogi formulát kapott (EC 2003 -1059/2003/EK rendelet). Az ebben a jegyzékben szereplő területi szintek egységeire általánosságban a régió (illetve a NUTS-régió) fogalmát használják, de a régió hivatalos definícióját nem adták meg (Szabó 2015). A NUTS-jegyzék a kezdeti formációhoz képest jelentősen kibővült, és 2016-ban már 28 tagállam regionális beosztásait tartalmazza. A NUTS az idők során több változáson ment át, egyes országokban - esetenként többször is - módosultak a regionális beosztások.

Nyugat-Európában a régiók fogalma, szerepe már akkor tudományos kutatások tárgya is volt, amikor hazánkban még inkább a körzet (rajon) fogalma volt használatban. A rendszerváltozás után azonban a körzet lassan kikopott a szakmai szótárakból, mivel a szocializmusban sajátos - a fennálló politikai rendszer jellegzetességeihez kötődő - tartalommal töltődött fel, és az egykor használatos fogalmakat nem kis ellenérzés kísérte (Horváth 2002). Hazánkban a régió fogalma hamar elterjedt és többféle értelmezést kapott (Szabó 2015), majd idővel hivatalos területi formációt is öltött a hét tervezési-statisztikai régió megszületésével, amelyek NUTS 2 szinten illeszkednek az EU területi jegyzékéhez.

A NUTS-rendszer ma stabil alapja az Európai Unió területi beosztási, statisztikai, regionális elemzési és regionális politikai rendszerének. Az Eurostat többszintű regionális adatgyűjtése egyre alaposabb, egyre szélesebb körü, információi szabadon hozzáférhetők, használhatók. A statisztikákban ma már a tagjelöltek és (az európai) nem tagállamok hasonló jellegű térfelosztásai is felbukkannak. A területi információk megjelennek mind a hivatalos helyzetérté- 
kelésekben, dokumentumokban (kohéziós jelentések, országok, régiók területfejlesztési anyagai), mind a tudományos kutatásokban, így például a kifejezetten az európai területi jellemzőket feltáró és előrejelzési kérdéseket is magában foglaló, közösségi szinten szerveződő ESPON-kutatásokban is.

A területi tervezéshez a regionális adatokból kibontakozó területi helyzetképek adják az egyik alapot az Európai Unió regionális politikája számára, sőt, évtizedek óta a regionális politikai támogatáselosztás kiemelt alapja is a régió. (Mindezt a támogatáspolitikától elválaszthatatlan politikai alkufolyamatok jelentőségéről nem elfelejtkezve emeljük ki.) Az Európai Unióban kezdetektől figyelembe vett cél a fejlettségi különbségek mérséklése (Horváth 1998), a 2014-2020-as ciklusban regionális politikai célokra már mintegy 350 milliárd euró áll rendelkezésére, amely az integráció költségvetésének harmadát teszi ki. Bár az évek folyamán némileg gyengült a felzárkóztatás célja, azaz a koncentráció alapelve, ugyanakkor ebben a ciklusban is a legtöbb támogatást (182 milliárd $€$ ) azon NUTS 2 régiók kapják, ahol az egy före jutó GDP nem érte el az EU átlagának 75\%-át. Így EU támogatásban részesül az EU lakosságának 27\%-a. (35 milliárd eurót a köztes régiók [75-90\%], 54 milliárdot a fejlett régiók [>90\%] kapnak; utóbbi régiókban él az integráció lakóinak mintegy 60\%-a). Az EU 2020 célkitűzései 11 témakörben - többnyire ágazati szemléletben - jelennek meg a szakpolitikákban, amelyek régi (foglalkoztatás, kis- és középvállalatok, oktatás stb.) és új kihívásokra (infokommunikáció, éghajlatváltozás stb.) próbálnak választ adni. Bár a kezdetekhez képest többször változtak a regionális politika célrendszerének területi vagy ágazati szempontú alanyai, ugyanakkor egy cél tartós maradt - amelyet legutóbb a Lisszaboni szerződés deklarált -, miszerint kiemelt feladat az elmaradott NUTS 2 régiók támogatása.

Ugyanakkor, ha végigtekintünk az elmúlt több mint negyedszázad területi alapú céljain (Faragó 2016), megállapíthatjuk, hogy - az elmaradottság enyhítésének prioritása mellett (első számú célkitűzés) - különböző szakaszokban különböző térségtípusok voltak előtérben. Az 1989-1993-as ciklusban az ipari válság sújtotta térségek és a vidéki területek fejlődésének előmozdítása két külön célkitűzés volt (2., 5b.), amelyekhez az 1994-1999-es időszakban hozzáadódott - Svédország és Finnország csatlakozása révén - a rendkívül alacsony ( $<8 \mathrm{fő} / \mathrm{km}^{2}$ ) népsűrűségű térségek fejlesztése is (6. célkitűzés). A 2000-2006-os periódusban az 1. célkitűzésben a legelmaradottabb NUTS 2 régiók mellé kerültek a ritkán lakott és tengeren túli régiók is, a 2. célkitűzésben jelent meg a strukturális nehézségekkel küzdő, gazdasági, társadalmi átalakulás sújtotta térségek támogatása (területi alapon). E kategóriában többféle térségtípus volt jelen: válságba jutott ipari térségek, válságba jutott halászati térségek, elmaradott rurális területek, problémákkal küzdő városi térségek (különböző kritériumok alapján). Ez a korszak magával hozta a támogatási arányok radikális megváltozását, mivel a 2004-es bővítés révén számos elmaradott és támogatásra jogosult ország és régió került az integráción belülre. Ez a helyzet többek között háttérbe szorította a speciális adottságú földrajzi térségeket, és a legutóbbi, 
2007-2013-as ciklus fö regionális politikai célkitűzései között már nem lelünk ilyen térségtípusokra, ahogy a jelenlegiben sem. Ugyanakkor ciklusról ciklusra egyre inkább felértékelődött két támogatandó térségtípus: egyrészt a határ menti zónák, másrészt a városi térségek.

A globalizálódó világban igény van a régió-, illetve az országhatárokat átívelö területi tervezésre és fejlesztésekre. Ennek felismerése már régen, még az EU-tól függetlenül megtörtént európai szinten. Különböző kezdeményezések születtek korábban, amelyek közül hazánkat is elérte egyik-másik: klasszikus példája volt az Alpok-Adria Munkaközösség, amely 1978-ban jött létre olasz, osztrák és német régiók, illetve Szlovénia és Horvátország kezdeményezésére, majd egy svájci kanton és magyar megyék is csatlakoztak a szervezethez (Horváth 1998). A közösségi politikán belül kezdetben a határ menti fejlesztésekre létrejövő, ún. közösségi kezdeményezésű Interreg program térségei jelenítették meg a határmentiség összetett problémáit. Később a határokon átnyúló európai területi együttműködés szerepének növekedésével és a közösségi kezdeményezésű programok megszűnésével (2007-től) újabb területi formációk alakultak ki: létrejöttek az Európai Területi Társulások (EGTC). Az Európai Unió 2006-ban teremtett lehetőséget arra, hogy az uniós források hatékony felhasználása, a már meglévő vagy jövőbeni együttműködések sikeressége érdekében két vagy több tagállam önkormányzatai, helyi, regionális szereplői jogi személyiséggel rendelkező csoportosulást, Európai Területi Társulást hozzanak létre. Számuk már meghaladja az ötvenet, és köztük számos magyar részvétellel jött létre.

A másik felívelés a nagyvárosokhoz kötődik, amelyek korábban a közösségi kezdeményezésű URBAN célterületei voltak. E program 2007-es lezárulása után a legújabb programozási időszakban a szakpolitika a közösségi eszközökből megvalósuló fejlesztések felét a városi területeken megvalósítandó beruházások támogatására kívánja fordítani. Ennek hátterében az áll, hogy a vidéki terek a közös agrárpolitika és a vidékfejlesztés keretében is támogatásokhoz jutottak, míg a nagyvárosok, főként a fejlett régiókban, csak csekély forrásokat tudtak megszerezni (hozzá kell tenni, hazai példák is mutatják, hogy sok vidéki támogatás nagyvárosi, fóvárosi cégek kasszáiban landolt). Az európai nagyvárosok ugyanakkor a társadalom és gazdaság fó koncentrációivá váltak a globalizálódó és tercierizálódó világban, ami sajátos problémákat okozott ezekben a terekben. Ennek felismeréseként nőtt meg a nagyvárosi támogatás súlya a regionális politikában (még az EU regionális politikai igazgatóságának neve is megváltozott: Directorate-General for Regional and Urban Policy), és 2016 tavaszán az Európai Unió tagországainak illetékes miniszterei aláírásával megszületett az Amszterdami paktum, amely az EU új városi ágendájának fó alapelveit rögzíti. Ez (is) egy új korszakot nyithat az EU fejlesztési politikájában (Faragó 2016).

Megítélésünk szerint ez a fordulat (amit érzékeltethetnénk akár a város és a régió fogalmi kettősségével, szembeállításával is) - noha már széles körben támogatókra lelt hazánkban és külföldön - nem magától értetődő és egyáltalán nem pozitív töltetủ hangsúlyváltozás, legalábbis a regionális politika lényegi 
tartalmát illetően. Ha a regionális politika a spontán piaci folyamatokon keresztül egyébként is kiemelt vonzerővel és haszonkoncentrációval rendelkező városi tereket preferálja, akkor azt is kockáztatja, hogy a teljes esélytelenség homályába űzi a ma is sokat emlegetett konvergenciacélokat (Fábián, Pogátsa 2016), amelyek kulcskérdése a leszakadó, elmaradott, kevésbé városias terek (társadalmának) felzárkóztatása.

\section{Összegzés: az egységesülés és tagozódás tartalma és tényezői}

Európa az emberiség történetében évezredes léptékben iránymutató globális szereplő. Ez a jegy a különböző történeti korokban eltérő tartalmú és súlyú (a gyarmatosítás századaira visszatekintő értékelésekben például erősen vitatott), a 2. világháborút követő időszakban, a modern globalizáció kibontakozásakor is meghatározó. A mai nyitott kontinens belső térfolyamatainak értelmezésekor megkerülhetetlenül jelen vannak a globális hatások és kihívások. Egyértelmüen kimutatható, hogy a regionális politika változása mögött ott vannak a mindezekre választ adni szándékozó irányváltások, így például a dinamikus városi terek fejlesztésének előtérbe kerülése - mint a globális versenyképességi lemaradás egyik lehetséges korrekciós eszköze.

Bizonyos elemeiben háttérbe szoruló, más nézőpontból és időszakokban ellenben elsőrendü tagoló tényező a kontinensen a makroregionális (a nemzeti szintek feletti térméretekben értelmezhető) megosztottság. A kontinens mérete, elhelyezkedése okán a természeti feltételeket, adottságokat illetően más földrészekhez képest kevésbé tagolt, még akkor is, ha a geográfusok többségének szemléletét sokáig a sokszínűséget hangsúlyozó vélekedés dominálta (Hajdú-Moharos 1988; Nemerkényi 2000). Ezzel szemben - s ez kifejezetten igaz a 20. század második felének évtizedeire - a politikai, katonai, hatalmi tagozódás mentén évtizedekig nagy blokkokba szervezetten (kényszerítetten) Európa a legmegosztottabb kontinens példája volt. Ezt a tagoltságot a szocialista rendszerek összeomlása, a rendszerváltozások alapjaiban változtatták meg. Mindezt kiteljesítő integráló hatása volt az Európai Unió keleti bővítésének. A területfejlesztés, a regionális politika oldaláról vizsgálva az EU - a fejlesztéspolitikai mechanizmust kifinomult eszközrendszerrel érvényesítő - az egyetlen kiteljesedett integráció példája ma is.

A természetföldrajzi és távolabbi történeti gyökerű társadalmi, kulturális különbségekhez kötődő tagoltság lassan oldódik (a tercierizálódó gazdaság- és társadalomszerkezet, a teljesen új eszközrendszerü kommunikációs-információs tér egyre nyilvánvalóbban új tényezőket, adottságokat tol előtérbe), ugyanakkor a környezeti szempont - globális problémákra visszavezethetően is - újra előtérbe állítja a természet-társadalom relációt. A fekvési, természet- és társadalomföldrajzi alapon kijelölt makrorégiók - ezzel együtt is ez idáig - mint el- 
méletileg szóba jöhető, egymástól elkülöníthető téregységek léptek színre, az ezekre kidolgozott fejlesztéspolitikai programok súlya és hatása csekély. A makroszintű összekapcsoltság erősítésének leglátványosabb eszközei a modern közlekedési hálózatok, tengelyek megteremtésére irányuló infrastrukturális fejlesztések. A Szovjetunió negyedszázaddal ezelőtti összeomlása után ma újraéledőben van egy korábbi politikai, hatalmi, katonai megosztottság, Oroszország geopolitikai törekvéseinek újjáéledésével.

Bár a térfolyamatokat irányító területi entitások befolyását - a globális trendeknek megfelelően - a gazdasági folyamatokban Európában is felváltotta a legnagyobb gazdasági szereplők aktivitása, a nemzeti, országos szint mindmáig megmaradt a legösszetettebb eszközrendszert birtokló irányítási szereplőnek. A térségi szintek viszonyát tekintve sem az Európai Unió létrejötte „felülről” (a nemzeti hatáskörök átvételével, szúkítésével), sem a decentralizáló, demokratizáló „régiók Európája” gondolat „alulról” nem hozott az országos szint meghatározó szerepében vitathatatlan, megfordíthatatlan változást. Napjainkban éppen azt az időszakot éljük, amikor a közösség, a tagállamok, és a „régiók” közötti hatalommegosztás problémája újra a viták előterébe kerül. Az országokon belüli tagolódásra, egyenlőtlenségekre koncentráló vizsgálatok általános tanulsága, hogy - akár az erősen központosított, centralizált, akár a „piacosabb", liberálisabb irányítási körülmények közepette is - a területi egyenlőtlenségek alakulásában elsődlegesen az országosan érvényes általános szabályozás hatásai a meghatározók és nem a speciális területi szabályozásé.

Az országon belüli regionális fejlettségi tagoltság a mai Európában is fejlettségfüggő. A keresztmetszeti összehasonlítások jól ismert elméleti és módszertani korlátait, a térfelosztásban, a téregységek számában meglévő különbségeket figyelembe véve, a különböző indikátorok használatával végzett minden területi fejlettségelemzés azt igazolja, hogy a legfejlettebb országok térségileg kiegyensúlyozottabbak, mint a gyenge-közepes fejlettségűek (a kontinensen visszaigazolva a klasszikus Williamson-hipotézis egyik sztochasztikus alapösszefüggését) (2. táblázat).

Az EU-hoz újonnan csatlakozott posztszocialista országok többségében a korábbi időszakban jellemzo”, „lefelé nivellált” társadalmi és térszerkezet helyébe egy jóval differenciáltabb séma lépett. Ez jellemző még akkor is, ha kontinentális léptékben az egységesülést legmarkánsabban hordozó integrációs szervezet kiemelt kohéziós célkitűzése és a hozzá rendelt támogatási eszközök szinte mindenütt hordoznak kiegyenlítő hatásokat. A tapasztalat azt mutatja, hogy e támogatási eszközök nem képesek ellensúlyozni a piaci erők erős, térben is differenciáló hatásait.

A regionalisták szakmai érdeklődésének középpontjában álló mezoterek (Nemes Nagy 2016) szerepe a modern Európában összességében kétségkívül erősödött, bár súlyukban, eszközrendszerükben máig jelentős különbségek vannak a kontinens országaiban. Európa több országa korábban több kisebb önálló entitás egyesülésével vált egyetlen egységgé, ezekben a legmélyebbek a 
2. táblázat: Az egy főre jutó GDP regionális (territorial level 3) különbségei az Európai Unió egyes tagállamaiban

Regional (territorial level 3) inequalities of GDP per capita in some EU member states

\begin{tabular}{|c|c|c|}
\hline Ország & Gini-index (2000) & Gini-index (2013) \\
\hline Szlovákia & 0,217 & 0,261 \\
\hline Lettország & 0,269 & $0,239^{*}$ \\
\hline Írország & 0,167 & $0,233^{*}$ \\
\hline Magyarország & 0,177 & $0,199^{*}$ \\
\hline Észtország & 0,206 & $0,192 *$ \\
\hline Lengyelország & 0,176 & $0,191^{*}$ \\
\hline Nagy-Britannia & 0,191 & 0,187 \\
\hline Litvánia & nincs adat & 0,171 \\
\hline Olaszország & 0,162 & $0,158^{*}$ \\
\hline Dánia & nincs adat & 0,152 \\
\hline Ausztria & 0,157 & $0,146^{*}$ \\
\hline Franciaország & 0,114 & $0,136^{*}$ \\
\hline Csehország & 0,119 & 0,135 \\
\hline Németország (NUTS2) & 0,135 & $0,127^{*}$ \\
\hline Portugália & 0,159 & 0,124 \\
\hline Szlovénia & 0,098 & 0,119 \\
\hline Spanyolország & 0,127 & $0,112^{*}$ \\
\hline Finnország & 0,116 & $0,086^{*}$ \\
\hline Belgium (NUTS2) & 0,082 & 0,073 \\
\hline Svédország & 0,063 & $0,071^{*}$ \\
\hline Hollandia (NUTS2) & 0,052 & $0,042^{* *}$ \\
\hline Görögország (NUTS2) & 0,018 & 0,019 \\
\hline
\end{tabular}

*2012, ${ }^{* *}$ 2010. Dólttel kiemelve a megnövekedett területi egyenlőtlenséget mutató országok. A territorial level 3 az OECD egyik régiókategóriája, az európai országok esetében ez döntően az EU NUTS3 szintjét jelenti. Forrás: http://www.oecd-ilibrary.org/governance/oecd-regions-at-a-glance-2016/

regionalitás történeti és társadalmi gyökerei (Olaszország, Németország). Van példa arra is, ahol országrésznyi méretü régiók szerepe a devolúciós átalakulások nyomán erősödött fel újra (Nagy-Britannia). Több országban éppen a legközvetlenebb múltban léptek erősödő regionális hatáskörök a centralizált irányítási séma helyébe. Ennek legújabb, talán legradikálisabb példája a 2015-ös francia decentralizálós fordulat, amely az egész kontinens egyik legrégebbi, központi területfejlesztési intézményét, a DATAR-t is megszüntetve feladta a felülről irányított „ellenpólusképzo”” területpolitika, sokáig virulens, de kevés eredményt hozó sémáját. A posztszocialista államoknak (amelyek közül több korábbi nagyobb országkeretből vált ki, önállósult a 20. század folyamán) egyik jellemző sajátos vonása, hogy a régiók szerepében - a külső forrásszerzési célokon túl - csak halványan érzékelheto” az eredeti „európai régió gondolatának” demokratizáló, decentralizáló, valóságos irányítási kompetenciákat feltételező tartalma, itt még mindig a nemzeti szintű összetartozás, a belső tagozódástól 
való tartózkodás a megkérdőjelezhetetlen prioritás. A decentralizációt fékező faktorok közül vitathatatlanul komoly (belső) dezintegrációs kockázatok hordozója számos országban (a kontinens nyugati felén éppúgy, mint a keletin) ma is az etnikai és az ezzel sok helyütt összekapcsolódó fejlettségi megosztottság.

Ide illeszthető az eddigi gondolatmenethez csak közvetetten kapcsolódó, bizonyos értelemben leginkább kutatásmódszertaninak tekinthető megjegyzésünk. A kontinens sokszínűsége és az egységesülés nagyon eltérő dimenziói arra is figyelmeztetnek, hogy ha - az elérhető gazdag információs bázis csábításának engedve - a területi folyamatok elemzése szolgaian leszúkül a hivatalosnak minősülő NUTS-rendszer téregységeire (azaz lényegében a közigazgatás térbeli kereteibe szorítjuk a teljes gazdasági és társadalmi kapcsolati hálót), akkor figyelmen kívül marad az a tény, hogy e rendszer és a „valóságos” térszerveződés között az inkonzisztencia rendkívül gyakori. Ez a társadalmi térelemzés eszközrendszerének gazdagítását, fejlesztését igényli (Jakobi 2015), anélkül, hogy a fejlesztéspolitikában kiemelt szerepü téregységek irányítási szerepét megkérdőjeleznénk.

Az egységesülés és tagozódás mozgatórugói, bonyolult hatótényezői közül egy társadalmi térelem mindenképp kiemelendő: a határok. Ezekre fókuszálva Európa elmúlt 60 évében az 1990 körüli kelet-közép-európai rendszerváltozások hozták a legalapvetőbb fordulatot. Azok többsége, akik mindkét időszakot átélték, bizonnyal megerősíti, hogy a volt szocialista országok társadalmában éppen a határok durva gátjellegének oldódása, majd sok helyütt teljes eltűnése (amelynek emblematikus történelmi példája a berlini fal leomlása volt) a várt „szabadságélmény” egyik meghatározó erejű hordozója. Míg a gazdasági fejlettség, a jólét, az életkörülmények tekintetében az ugyancsak sokak által remélt gyors felzárkózás, kontinentális léptékű közeledés még várat magára, a határok funkcióinak változása, ha nem is tüntette el, de sok tekintetben kompenzálta a gyors felzárkózási illúzió beteljesületlenségét az egyének szabadabb mozgása, az anyagi és szellemi javak kevésbé fékezett áramlásának előnyei révén.

A kézirat leadásának napjaiban, a Brexit és a menekültválság okán épp az egységesülés és a tagozódás újabb kritikus időszakába léptünk. E két megkérdöjelezhetetlenül nagy hatású esemény, a maga bonyolult társadalmi és politikai összefüggéseivel ma még inkább csak a politikai és a publicisztikai diskurzusnak ad témát, kiváltó okainak és kimenetének tudományos mélységü megítélése még idő előttinek tűnik. Az azonban aligha vitatható, hogy mindkettő szorosan összefügg nemcsak a kontinens általános jövőjével, hanem tanulmányunk alaptémájával is. Csak egyetlen lehetséges következményt kiemelve: napjaink menekülthulláma - a valós kockázatok mentén vagy esetenként belpolitikai hivatkozási ürügyként - a kontinens nyílt áramlási terében a határok gátszerepét újraépítő folyamatokat indíthat el. Ha ezek valóban beindulnak, Európa visszazuhanhat az elzárkózás és a megosztottság korábbi állapotába, amelynek elsődleges kárvallottjai a periféria országainak polgárai lesznek. 


\section{Irodalom}

Braudel, F. (2003): Franciaország identitása. 1. kötet. A tér és a történelem. Helikon Kiadó, Budapest

Cséfalvay Z. (1999): Helyünk a nap alatt... Magyarország és Budapest a globalizáció korában. Kairosz Kiadó, Budapest

Decand, G. (1997): The Nomenclature of Territorial Units for Statistics (NUTS). In: Eurostat: Proceedings of the seminar on regional statistics - Baden 1996. Office for Official Publications of the European Communities, Luxembourg

ESPON (2004): Potentials for polycentric development in Europe. ESPON, Nordregio https://www.espon.eu (Letöltés: 2016. szeptember 10.)

ESPON (2014): Making Europe open and polycentric. The territorial vision for Europe - ET 2050. ESPON, MCRIT Ltd. http://www.eurometrex.org (Letöltés: 2016. szeptember 10.)

European Communities (1988): Regulation (EEC) No 2052/88 of 24 June 1988 on the tasks of the Structural Funds and their effectiveness and on coordination of their activities between themselves and with the operations of the European Investment Bank and the other existing financial instruments. Office for Official Publications of the European Communities, Luxembourg

European Communities (1994): Europe 2000+. Cooperation for European territorial development. Office for Official Publications of the European Communities, Luxembourg

European Communities (1999): Regions - Nomenclature of territorial units for statistics (NUTS). Office for Official Publications of the European Communities, Luxembourg

European Communities (2001): Second report on economic and social cohesion. Office for Official Publications of the European Communities, Luxembourg

European Communities (2003): Regulation (EC) No 1059/2003 of the European Parliament and of the Council of 26 May 2003 on the establishment of a common classification of territorial units for statistics (NUTS).

European Communities (2012): Területi Agenda 2020. http://regionalispolitika.kormany.hu/teruletiagenda-2020-es-hatteranyagai (Letöltés: 2016. szeptember 4.)

European Communities (2016): EU expenditure and revenue. http://ec.europa.eu/budget/figures/ interactive/index_en_cfm (Letöltés: 2016. július 25.)

Erdősi F. (2004): Európa közlekedése és a regionális fejlődés. Dialóg Campus Kiadó, Budapest, Pécs

Faragó L. (2016): Az EU területi politikájának változásai közép-kelet-európai nézőpontból. Tér és Társadalom, 2., 3-22. http://doi.org/bsnm

Fábián A., Pogátsa Z. (szerk.) (2016): Az európai kohéziós politika gazdaságtana. Akadémiai Kiadó, Budapest

Gottmann, J. (1954): A geography of Europe. Henry Holt and Company, New York

Grigg, H. (1998): The consumption of alcoholic beverages in Europe and the former USSR. Geography, 3., 283-287.

Hajdú-Moharos J. (1988): Történeti-gazdasági területegységek Európa országaiban. Tankönyvkiadó, Budapest

Heidenreich, M. (2003): Regional inequalities in the enlarged Europe. http://www.uni-bamberg.de (Letöltés: 2016. szeptember 4.)

Horváth Gy. (szerk.) (1993): Régiók és városok az olasz modernizációban. MTA Regionális Kutatások Központja, Pécs

Horváth Gy. (szerk.) (1997): Régiók felemelkedése és hanyatlása. Regionális fejlődés és politika a Brit-szigeteken. MTA Regionális Kutatások Központja, Pécs

Horváth Gy. (1998): Európai regionális politika. Dialóg Campus Kiadó, Budapest, Pécs

Horváth Gy. (2000): Partnerség az Európai Unió regionális politikájában. Tér és Társadalom, 1., 11-26.

Horváth Gy. (2002): Régiók Magyarországa. In: Enyedi Gy., Horváth Gy. (szerk.): Táj, település, régió. MTA Társadalomkutató Központ, Kossuth Kiadó, Budapest, 393-459. (Magyar tudománytár; 2.)

Horváth Gy. (2003): Regionális támogatások az Európai Unióban. Osiris Kiadó, Budapest

Horváth Gy. (2006): Regionális versenyképesség Európában. In: Horváth Gy. (szerk.): Régiók és települések versenyképessége. MTA Regionális Kutatások Központja, Pécs, 84-105.

Horváth Gy. (2015): Spaces and places in Central and Eastern Europe: Historical trends and perspectives. Routledge, London 
Hospers, J. (2002): Beyond the blue banana? Structural change in Europe's geo-economy. Paper for 42nd European Congress of the Regional Science Association. Young Scientist Session, Dortmund

Jakobi Á. (2015): A grid: aggregált és dezaggregált rácsmodellek a területi egyenlőtlenségek vizsgálatában. Területi Statisztika, 4., 322-338.

Jordan, T. G. (1996): The European culture area. A systematic geography. Harper Collins, New York

Kincses Á., Nagy Z., Tóth G. (2013): Európa térszerkezete különböző matematikai modellek tükrében, I. rész. Területi Statisztika, 2., 148-156.

Kozma G. (2003): Regionális gazdaságtan: geográfus és földrajz tanár szakos hallgatók számára. Egyetemi jegyzet. Kossuth Egyetemi Kiadó, Debrecen

Kunzmann, K. R. (1992): Zur Entwicklung der Stadtsysteme in Europa. Mitteilungen der Österreichischen Geographischen Gesellschaft, 134., 25-50.

Landesmann, M. (2013): The new North-South divide in Europe - can the European convergence model be resuscitated? The Vienna Institute for International Economic Studies, Monthly Report, $1 / 2013$.

Lever, W. (1995): The European regional dimension. In: Lever, W., Bailly, A. (eds.): The spatial impact of economic changes in Europe. Ashgate, Vermont, Avebury, 178-203.

Nagle, G., Spencer, K. (1999): Az Európai Unió földrajza. Regionális és gazdasági megközelítésben. Holnap Kiadó, Budapest

Nemerkényi A. (2000): Európai természeti viszonyai. Európai nagytájak. In: Probáld F. (szerk.): Európa regionális földrajza. ELTE Eötvös Kiadó, Budapest, 7-84.

Nemes Nagy J. (2009): Terek, helyek, régiók. A regionális tudomány alapjai. Akadémiai Kiadó, Budapest

Nemes Nagy J. (2016): Mezoterek a társadalomban és a gazdaságban. In: Lengyel I., Nagy B. (szerk.): Térségek versenyképessége, intelligens szakosodása és újraiparosodása, JATEPress, Szeged, 105-124.

OECD (2016): Regions at a glance. http://www.oecd-ilibirary.org/governance/oecd-regions-at-a-glance-2016 (Letöltés: 2016. szeptember 25.)

Pap N. (1997): Európai korridorok. In: Pap N., Tóth J. (szerk.): Európa politikai földrajza. JPTE TTK, Pécs, 49-64.

Pounds, N. (1997): Európa történeti földrajza. Osiris Kiadó, Budapest

Probáld F. (2000): Európa társadalomföldrajzi vázlata. In: Probáld F. (szerk.): Európa regionális földrajza. ELTE Eötvös Kiadó, Budapest, 99-124.

Probáld F., Szabó P. (2005): Európa térszerkezetének modelljei. In: Dövényi Z.,Schweitzer F. (szerk.): A földrajz dimenziói. MTA Földrajztudományi Kutatóintézet, Budapest, 159-170.

Rechnitzer J. (1998): Területi stratégiák. Dialóg Campus Kiadó, Budapest, Pécs.

Rechnitzer J. (1999): Az állami vagyon magánosításának területi dimenziói. Tér és Társadalom, 3., $101-120$.

Sárfalvi B. (1968): Európa népessége és gazdasága. In: Marosi S., Sárfalvi B. (szerk.): Európa. Gondolat Kiadó, Budapest, 53-86.

Sárfalvi B. (1994): Korunk világgazdasága. In: Probáld F. (szerk.): Európa regionális földrajza. Nemzeti Tankönyvkiadó, Budapest, 25-47.

Soós E. (1996): Feszültségek az Európai Unió regionális bizottságában. Comitatus, 7-8., 107-117.

Sütő, A., Salamin, G., Szabó, P. (2010): Issues of territoriality and territorial cohesion in the revision of the TSP and the territorial agenda - a sort of connection betweeen geography and regional policy. Forum Geographic, 9., 145-154.

Szabó P. (2009): Európa térszerkezete különböző szemléletek tükrében. Földrajzi Közlemények, 2., 121-134.

Szabó P. (2015): Régió és térszerkezet az elmélettól a területpolitikáig. ELTE Eötvös Kiadó, Budapest

Terrasi, M. (2003): The macrospatial dimension of European integration on the threshold of the new enlargement. Paper for Conference of RSA, 2003.04.12-15., Pisa 